\title{
Investigating Primary School Teachers' Knowledge Towards Meanings of Fractions
}

\author{
Adem Doğan ${ }^{1} \&$ Neşe Işık Tertemiz ${ }^{2}$ \\ ${ }^{1}$ Kahramanmaraş Science and Art Center, Kahramanmaraş, Turkey \\ ${ }^{2}$ Gazi University, Gazi Faculty of Education, Ankara, Turkey \\ Correspondence: Adem Doğan, Gazipaşa, Sehit Ilbey Street No: 7 Dulkadiroglu, Kahramanmaras, Turkey.
}

\author{
Received: January 8, 2019 \\ Accepted: February 22, 2019 \\ Online Published: May 29, 2019 \\ doi:10.5539/ies.v12n6p56 \\ URL: https://doi.org/10.5539/ies.v12n6p56
}

\begin{abstract}
The concept of fraction and the concepts related to the fraction have an important place in primary and secondary school education programs. In this respect, primary school teachers need to be careful about the concept and sub-meaning of the fraction. In this study, general survey model was used to determine the level of knowledge of the primary school teachers about the meaning of fractions. A total of 266 primary school teachers (149 female and 117 male) participated in the study in Turkey. For collecting data, a success test was developed by the researchers about the meaning of the fraction. The data were analyzed by using SPSS 21 package program. The general success average of the teachers was found to be $60.2 \%$. The most successful sub-meaning of the fraction is the operator meaning with $80 \%$ and the least successful meaning is ratio meaning with $48 \%$. Furthermore, it was concluded that there is a positive correlation with each other in all sub-meanings fractions.
\end{abstract}

Keywords: primary school teachers, concept of fraction, sub-meaning of fractions, measure, part-whole, ratio, quotient (division) and operator

\section{Introduction}

Mathematics generally is a system created in the mind of the human. There are ideas, thoughts and relations in its structure. These are the results of successive and mental abstractions. A generalization is made by creating integrated circuits of each other. Mathematics is a generalization that is made by forming the integrated circuits of these. In other words, it can be said that the reasoning method is used.

In terms of the structure of mathematics, prerequisites are one of the areas where the relationships are the highest (Baykul, 2005). In mathematics teaching, any concept cannot be taught without gaining other concepts in its prerequisite (Altun, 2013). Bloom (1976), as a result of his research, states that the pre-requisite for learning a particular learning unit in areas such as mathematics, is related to the learning at the end of the lesson or at the end of the semester and that the pre-requisite learning affects the subsequent learning. Mathematics subjects have a stronger spiral and sequential structure than the other sciences.

Mathematics education aims to educate people who do know mathematics and apply the knowledge of mathematics, do mathematics and solve problems (Olkun \& Toluk, 2003). For this reason, knowledge societies of the 21 st century need to go beyond basic skills and acquire "new qualifications" (Gür \& Korkmaz, 2003). In this sense, the nature of mathematics teaching needs to be changed and the learning environment and opportunities should be prepared by teacher in a way that will allow to use the intellectual processes of his/her students.

Many conditions such as the adequacy of mathematics curricula, teachers' equipment, the appropriateness of the educational materials to the new generation of children, and the contribution to education of out of school time, affect education. In such cases, our country level is answered with unattractive results in international exams such as PISA (Programme for International Student Assessment) and TIMSS (Trends in International Mathematics and Science Study) (PISA National Report, 2015 and TIMSS National Report, 2015).

In the age of technology, the importance of knowledge is rapidly increasing, so the concept of knowledge and understanding of science are changing. As technology advances many concepts are differentiated, and the skills that societies expect from individuals to change with all these changes are changing (Millî Eğitim Bakanlığı [MEB], 2005). Depending on this, the education of the teachers who will carry out the change is becoming more and more important. 
One of the most strategic elements of the education system is the teacher (Bursalığlu, 2002). It is inevitable that the characteristics of the teacher affect the teaching process activities (Uğurlu \& Polat, 2011). Therefore, it can be said that the achievement to the goal of education largely depends on the performance of the teacher in the classroom environment (Baloğlu, 2001). According to Karacaoğlu (2008, p. 71), the increase in the quality of teacher education affects the student's learning.

Although teacher education is given at faculty level in university, the level of teachers' qualifications is not only related to this education. Preschool education, primary, middle and high school education also determine the quality of students coming to the faculty of education. Moreover, the lack of training on teachers' training means that the human capital required for the development of the education level of our country is much lower than the existing one. Therefore, enhancing teacher quality should be a national priority, especially for primary school teachers.

Shulman (1986), "The teacher what should know?" "The teacher what should do when explaining the lesson?" based on the questions that teachers should have, considering the relationship between teachers' subject knowledge and the way they present it to the students. He revealed a new model about the knowledge that teachers should have field knowledge, knowledge of the curriculum and pedagogical knowledge. Therefore, he re-established the teacher knowledge model that knowledge of the field, knowledge of the curriculum and pedagogical content knowledge. In addition to these three areas of knowledge, the teacher must have many qualifications such as self-renewal, effective use of technology, openness to innovations and lifelong learning.

Teachers have a great responsibility for effective training activities. The creation of the training environment, the selection of teaching materials and teaching methods, and the efficient implementation of the activities are some of these responsibilities. The level of knowledge of teachers, who play an active role in the positive changes in the students' behavior and leave important traces in students' lives, is considered to be very important (Ekiz, 2011). In this context, it can be seen that primary school teachers are able to present mathematical subjects and provide an effective teaching process to their students.

As mathematics contains many abstract concepts in terms of general subjects, it can cause many misconceptions. For this reason, a lot of research has been done on misconceptions that may occur during mathematics teaching. One of the most abstract and hardly understood subjects of mathematics, it is the concept of fraction that contains many concepts, which cannot be immediately understood and even have sub-meanings within itself (Aksu 1997; Booker 1998; Brown \& Quinn, 2006; Işık, 2011). Learning and understanding of fractions for both primary and secondary school students is an important problem. In addition, it was revealed that students were weak in understanding the concept of fraction as a result of many studies (Saxe, Taylor, McIntosh, \& Geahart, 2005; Wearne \& Kouba, 2000; Van de Walle, Karp, \& Bay-Williams, 2014; Sowder \& Wearne, 2006; Bray \& Abreu-Sanchez, 2010).

It is stated that different personal experiences would be beneficial, so that the students can understand a fraction in different situations, that is, to meet different situations and to gain different personal experiences in order to comprehend different meanings and expressions of the fraction (Ersoy \& Ardahan, 2003).

In general, it is stated that a fractional expression such as a / b can be interpreted in five different ways (Behr, Harel, Post, \& Lesh, 1993; Lamon, 2007; Pantziara \& Philippou, 2012). These are often summarized as part-whole, measure, ratio, quotient (division) and operator. Fraction models can be used in all of these five contexts.

\subsection{Part-Whole Sub-Meaning}

The part-whole sub-meaning of a fractional expression, such as a / b, generally involves the physical or mental fragmentation of the whole (Sowder, 1995). In the part-whole expression of the fraction, it is shown that a whole is divided into pieces of equal size. It can be said that this sub-meaning of the fraction is the most commonly used and the easiest to understand.

The part-whole sub-meaning of the fraction is related to the other four meanings of the fraction, albeit in different proportions. The whole meaning of the fraction is related to the other four meanings of the fraction, although in different proportions. Charalambous and Pitta-Pantazi (2005) point out that part-whole sub-meaning of the fraction is closely related to the processor and ratio sub-meaning of the fraction and is less related to measure and quotient sub-meaning of the fraction. They also stated that the concept of part-whole is essential to learn the concept of fraction but that this concept is not enough alone. In the curriculum of primary school mathematics lesson (1- 4 classes), it is emphasized that the part-whole sub-meaning of the fraction is focused. 


\subsection{Measure Sub-Meaning}

Lamon (2012) stated that the meaning of the measure is related to two concepts which are close to each other, firstly; as a number that states how large the fractions are numerically, the second one; it is considered to be the relation with the measures used to determine a distance from the starting point assigned to the specific intervals. In terms of measure, fractions refer to whole numbers, but the measure sub-meaning of the fraction quantities such as length, area, weight, volume and time in the range of integers.

The measure meaning of the fraction is based on three principles of measurement (Flores, Samson, \& Yanik, 2006; Stephan \& Clements, 2003; Yanik, Helding, \& Flores, 2008). Firstly, it is the inverse ratio between the measurement unit and the amount of repetition of that unit. In other words, the smaller the measurement unit, the greater the amount of repetition during the measurement process. The second principle is that the measurement unit can be reduced as desired. The third principle is that the unit can be repeated up to the desired unit between two ends of a length or plurality to be measured.

The measure meaning of the fraction is also important for understanding the density characteristic of rational numbers. According to this feature there are an infinite number of rational numbers between two rational numbers. This can be represented as placing the other rational number or numbers in the range obtained by expressing two different rational numbers (equalizing the denominators) in the same unit in fraction (Yanık, 2015).

\subsection{Ratio Sub-Meaning}

The ratio is expressed as a numerical representation of the proportional relationship between the multiplicities of the same or different measurement spaces (Van de Walle et al., 2014). The ratio meaning of the fraction means the relationship between the multiplicities. This is like the relationship between apples and oranges in a fruit basket (Post, Cramer, Harel, Kiernen, \& Lesh, 1998). The ratio meaning of the fraction can be written in the form of a / b. The multiplicities like $\mathrm{a}$ and $\mathrm{b}$ are proportionally compared with each other.

The meaning of the fraction ratio is seen as a comparison sign rather than a number because it expresses the relation of the linked amounts. However, Siegler, Thompson, and Schneider (2011) have highlighted the phenomenon of odds with the emphasis on the proportions of the multiplicities of different measurement spaces. An example of this is the sugar / water ratio can be given when mixed with 1 part of sugar and 2 parts of water in a solution to give the density of the solution and the unit of this ratio will be sugar/water (Akar, 2009).

The ratio meaning of fractions is closely related to the ability to think proportionally. It includes the ability to interpret and make decisions about the nature of the comparison by considering the relative variations of the proportional multiplicities at the same time (Lesh, Post \& Behr, 1988).

\subsection{Quotient Sub-Meaning}

According to the quotient meaning of the fraction, it is considered as the numerical value obtained that the result of a divide operation when the number a is divided by the number b (Kieren, 1993). In here the number "a" is divided and " $b$ " is the dividing state. The symbols can also be used as a fraction symbols that fraction bar or " " " and "־". For example: 12 pens will be shared by 4 students. "How many pens takes each student?" like the answer to the question.

The ability of children to express the remainder as fraction may not give sufficient insight into how meaningful these fractions for children. The main source of many problems experienced by the children about the remained divisions, the fractions aren't well understood (Toluk, 2002). For the development of the meaning of division of students define fractions as division process and the division and the divisor must understand by students the role in this process (Charalambos \& Pitta-Pantazi 2005).

\subsection{Operator Sub-Meaning}

Toluk (2002) states that operator sub-meaning of rational numbers represents the rule of multiplication process. Charalambos and Pitta-Pantazi (2005) state that operator sub-meaning of fractions can be considered as a compound process which is a result of two multiplicative processes or a combination of two discrete but related processes. In terms of operator meaning, rational numbers are considered to be a process (function) applied to a number, object or cluster (Behr, Harel, Post, \& Lesh, 1993). In both cases, this process can be considered as applying the numerator to the amount in hand, and then applying the denominator to this result or the exact opposite. So; When $\mathrm{p} / \mathrm{q}$ is applied to a length $\mathrm{L}$, the $\mathrm{L}$ length is expanded to $\mathrm{p}$ times and is $\mathrm{q}$ times reduced or when $\mathrm{p} / \mathrm{q}$ is applied to a cluster of $\mathrm{n}$ elements, the cluster is first becoming a cluster with n.p, then it turns into a cluster with n.p/q elements (Kadhi, 2005).

When the primary school and secondary school mathematics teaching programs (2017-2018 academic year) are 
examined, it is located in all grade levels from 1st to 8th grade. When Primary School Mathematics (1 - 4 Grade) the curriculum is examined, the concept of fraction and its related outcomes; $18 \%$ in the first grade; $18 \%$ in $2 \mathrm{nd}$ grade; $23 \%$ in 3 nd grade and $28 \%$ in 4 nd grade; the mathematics curriculum for grades $1-4$ is average of 22 . When the Middle School Mathematics Curriculum (5 - 8 Grades) is examined, it is seen that about $30 \%$ of mathematics subjects are related to the concept of fraction. Considering the total of primary and secondary school education program, the concept of fraction and acquisitions related to the concept of fraction correspond to about one fourth of total gains from 1st grade to 8th grade (MEB, 2013; MEB, 2015).

In recent years, many studies (Arcavi, 2003; Bezuk \& Armstrong, 1993; Hasemann, 1981; Işıksal, 2006; Keijzer \& Terwel, 2003; Rule \& Hallagan, 2006; Steffe, 2002; Poison, 2013) have been done to make teachers and students realize the different meanings of the fraction and the misconceptions for fractions are focused on. The fact that these misconceptions do not occur when the subject of fractions are taught, and that the misconceptions have been realized, and the elimination of the misconceptions in the following stages, depends on the good level of knowledge of the teachers during the teaching. It is suggested in researches (Ball, Hill, \& Bass, 2005; Biber et al. 2013; Işık \& Kar, 2012; Toluk-Uçar, 2011; Yenilmez \& Ata, 2013) that in order to prevent the mistakes made by the students about the fractional and fractional meanings is recommended that teachers should plan the instruction and give examples in this direction by predicting these misconceptions. As seen in all these studies, there are still a lot of problems about the fraction. The absence of these problems is mostly due to the fact that classroom teachers do well in this field.

Considering that the subject of fractions has an important place in elementary and middle school mathematics education programs and it is important in terms of forming the basis of many subjects, this study has emerged in order to determine the knowledge of the primary school teachers about the meanings of the fraction.

\subsection{Research Questions}

This study aims to determine the knowledge of the primary school teachers about the meanings of the fraction. For this purpose, answers to the following questions are sought.

a) What is the knowledge of the primary school teachers about the general meaning of the fraction?

b) What is the knowledge of the primary school teachers about each sub-meaning of the fraction?

c) What kind of relationships are there among the primary school teachers' knowledge for the different meanings of the fraction?

\section{Methodology}

In this study, general scan model was used to determine the knowledge of the primary school teachers about the meanings of the fraction. General scan models are a research method on a sample or sample taken from the whole of the universe or a group in order to judge a subject for the universe in a universe of many elements. General scan models are, in a universe, consisting of so many elements, the models of scanning on the whole universe or else one group or a sample of it which is used for getting a general idea (Karasar, 2012, p. 79). A descriptive study was conducted to investigate the relationship between variables in the form of the relationship between researches the primary school teachers' general knowledge about the fraction and their sub-meanings. The research is a descriptive study that investigates the relationships between the variables of class teachers as to whether there is a relationship between the general and each sub-meaning of the fraction.

\subsection{Study Population and Sampling}

In this study, the sample group was selected from non-random sampling types by purpose sampling method. 
Table 1. Characteristics of primary school teachers who participating in the study

\begin{tabular}{|c|c|c|c|c|c|}
\hline \multicolumn{2}{|c|}{ Attendee Features } & Female & Male & Total (n) & Percent $(\%)$ \\
\hline \multirow{6}{*}{ 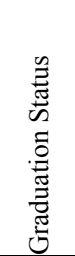 } & Faculty of Education & 101 & 82 & 183 & 68,8 \\
\hline & Faculty of Arts and Sciences & 13 & 7 & 20 & 7,5 \\
\hline & Institute of Education & 6 & 9 & 15 & 5,6 \\
\hline & Postgraduate & 13 & 7 & 20 & 7,5 \\
\hline & Other & 16 & 12 & 28 & 10.5 \\
\hline & Total & 149 & 117 & 266 & 100 \\
\hline \multirow{6}{*}{ 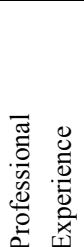 } & $4-8$ Years & 34 & 12 & 46 & 17,3 \\
\hline & $9-13$ Years & 31 & 21 & 52 & 19,5 \\
\hline & $14-18$ Years & 30 & 27 & 57 & 21,4 \\
\hline & $19-23$ Years & 33 & 26 & 59 & 22,2 \\
\hline & 24 Years and Over & 21 & 31 & 52 & 19,5 \\
\hline & Total & 149 & 117 & 266 & 100 \\
\hline
\end{tabular}

Purpose sampling is a kind of sampling that allows for rich in data collection and in-depth research depending on the purpose of the study (Büyüköztürk, Kılıç-Çakmak, Akgün, Karadeniz, \& Demirel, 2016). Criterion sampling was chosen from species of purposive sampling, the basic understanding of criterion sampling is to study all situations that meet a predetermined set of criteria. The criteria may be created by the researcher or a list of criteria prepared previously can be used (Yıldırım \& Şimşek, 2013, p. 112). In the sample of this study, it has been considered as a criterion for the fact that the primary school teachers have been educated at least once from the first grade to the 4th year and they are still active in the teaching process. The characteristics of the primary school teachers participating in the study are given in the table 1 .

149 female primary school teachers and 117 male primary school teachers, total of 266 primary school teachers, participated in the study. The majority of the primary school teachers attended was graduated from the faculty of education. In the sense of professional experience, it can be said that the number of primary school teachers participating in the success test is similar.

\subsection{Data Collection Tool}

In the study, a success test was developed to measure the level of knowledge of the primary school teachers about the sub-meaning of the fraction, knowledge on the development stages of this success test and reliability and validity studies are given below.

In order to determine the level of knowledge of the primary school teachers about the sub-meaning of the fraction, the literature review was done and a draft tool consisting of open-ended questions was prepared. When preparing the questions, education programs about the subject in the Primary School Mathematics Course (1-4 Grades) Curriculum (MEB, 2015), Secondary School Mathematics Course (5-8 Grades) Curriculum (MEB, 2013), PISA and TIMSS the questions are considered. The draft of the measurement tool consists of a total of 24 questions, 5 for the part-whole meaning of the cut, 4 for the meaning of the measure, 4 for the meaning of the ratio, 5 for the meaning of division and 6 for the meaning of operator. After taking the opinion of 6 field experts who were doctorate in mathematics teaching in this outline of the measurement instrument and making necessary corrections, reliability and validity studies were conducted in relation to the psychometric properties of the test.

\subsubsection{Reliability of Success Test}

Many definitions of reliability, which is one of the most important characteristics of the measurement tool, have been made. While Turgut (1997) sees the measurement results as a measure of free of errors, Crocker \& Algina (1986) defines the measurements made to measure a certain feature as the repeatability of the same individuals in similar situations. The reliability is related to how accurately the property is measured by the test. The correlation coefficient calculated as the reliability coefficient of the test results is also used to interpret the extent to which the actual variance of the test scores depends on the error factor (Büyüköztürk et al., 2016, p. 109).

Since a single application-based test will be used in this work, Kuder-Richardson-20 (KR-20) formula was used as the reliability index in other words internal consistency coefficient. The KR-20 formula is a statistical reliability formula used when the answers given to a test item are scored with 1 (true) and 0 (false) (Büyüköztürk et al., 2016). The internal consistency measures of the prepared success test (KR-20) were found to be 0.795 . According to Özdamar (2002), the reliability coefficient is medium level reliable at $0.60<\alpha<0.79$ when $0.80<\alpha<1.00$. it is highly reliable. According to this, it can be said that the success test which is prepared to measure the level of 
knowledge of the primary school teachers about the meanings of the fraction has sufficient reliability.

Table 2. Total test and item-total statistics for success tests

\begin{tabular}{ccccc}
\hline $\begin{array}{c}\text { Question } \\
\text { Items }\end{array}$ & $\begin{array}{c}\text { Average if the item is } \\
\text { deleted }\end{array}$ & $\begin{array}{c}\text { Variance in case the item is } \\
\text { deleted }\end{array}$ & $\begin{array}{c}\text { Corrected Item Total } \\
\text { Correlation }\end{array}$ & $\begin{array}{c}\text { In case of deletion of the substance. } \\
\text { KR-20 }\end{array}$ \\
\hline Question 1 & 7.91 & 12.259 & 0.268 & 0.789 \\
Question 2 & 8.24 & 11.330 & 0.436 & 0.778 \\
Question 3 & 8.25 & 11.712 & 0.317 & 0.787 \\
Question 4 & 8.04 & 11.721 & 0.368 & 0.783 \\
Question 5 & 8.06 & 11.462 & 0.446 & 0.777 \\
Question 6 & 8.40 & 11.510 & 0.399 & 0.781 \\
Question 7 & 8.44 & 11.358 & 0.465 & 0.775 \\
Question 8 & 8.24 & 11.508 & 0.380 & 0.782 \\
Question 9 & 8.42 & 11.474 & 0.418 & 0.779 \\
Question 10 & 8.52 & 11.856 & 0.339 & 0.785 \\
Question 11 & 8.38 & 11.743 & 0.320 & 0.787 \\
Question 12 & 8.09 & 11.646 & 0.370 & 0.783 \\
Question 13 & 8.47 & 11.420 & 0.460 & 0.776 \\
Question 14 & 7.89 & 11.899 & 0.450 & 0.779 \\
Question 15 & 8.13 & 11.617 & 0.365 & 0.783 \\
Question 16 & 8.00 & 11.584 & 0.444 & 0.778 \\
Average & 8.218 & 11.631 & 0.390 & KR-20=0.795 \\
\hline
\end{tabular}

Item-total score correlations are expected to be greater than 0.25 for the item selection. Obtaining close to zero or negative values indicates that the substance is insufficient to measure the subject to be measured (Erkuş, 2003; Özdamar, 2002). Therefore, the scores lower than 0.25 were removed from the test, in the last case, the lowest was 0.27 and the highest was 0.47 .

As a result of the analysis of the success test for sub-meaning of the fraction, the remaining 16 questions, item difficulty indices increased between 0.25 and 0.87 . It can be said that the matter is easy for primary school teachers when the substance difficulty index approaches 1 . According to the data obtained, the difficulty index of the 10th item, which is the most difficult substance in the test, is 0.25 . The easiest substance is the 14th item with 0.87 difficulty index. Accordingly, it can be said that the questions in the success test cover three levels as easy, moderate and difficult. It can be said that this success test has a medium difficulty test because the item difficulty index is 0.55 . In Table 3 below, item analysis of the Success test and item discrimination index and item discrimination were given.

Table 3. Item analysis of success test

\begin{tabular}{|c|c|c|c|c|c|}
\hline Question Items & $\begin{array}{c}\text { Substance Difficulty } \\
\text { Index }\left(\mathrm{P}_{\mathrm{j}}\right)\end{array}$ & Substance Distinction (r) & Question Items & $\begin{array}{c}\text { Substance Difficulty } \\
\text { Index }\left(\mathrm{P}_{\mathrm{j}}\right)\end{array}$ & Substance Distinction (r) \\
\hline Question 1 & 0.85 & 0.39 & Question 9 & 0.34 & 0.62 \\
\hline Question 2 & 0.53 & 0.72 & Question 10 & 0.25 & 0.49 \\
\hline Question 3 & 0.52 & 0.56 & Question 11 & 0.38 & 0.59 \\
\hline Question 4 & 0.73 & 0.56 & Question 12 & 0.68 & 0.53 \\
\hline Question 5 & 0.71 & 0.69 & Question 13 & 0.29 & 0.56 \\
\hline Question 6 & 0.36 & 0.56 & Question 14 & 0.87 & 0.49 \\
\hline Question 7 & 0.32 & 0.62 & Question 15 & 0.64 & 0.62 \\
\hline Question 8 & 0.53 & 0.66 & Question 16 & 0.76 & 0.62 \\
\hline
\end{tabular}

(*Average Item Discrimination, $\mathrm{r}=0.58)$

Chase (1999) stated that items with difficulty values between 0.20 and 0.85 could be considered good as psychometric. It is possible to say that the test of success for the meaning of the fraction in terms of item difficulty index is good. 
When the results of item discrimination index of the success test are examined, it is seen that this value is between 0.39 (question 1) and 0.72 (question 2). In order to be considered as a good discriminant in a test, the substances are stated to be between 0.30 and 0.40 ; whereas the above items with a value of over 0.4 are considered as "very good" and are reliable (Grove, Burns, \& Gray, 2012). According to this situation, it is seen that the success test is in a quite good condition according to the difficulty index and there is no item to be excluded from the test.

In addition, the level of significance between the $27 \%$ subgroup and the upper group scores of $27 \%$ was examined data from the group of 102 people who applied the questions in order to see the power of discernment of the success test. The t-test was applied to the total scores obtained from the lower and upper groups and the following results were obtained.

Table 4. Comparison of lower and upper groups total scores of success test with independent groups t-test

\begin{tabular}{ccccccc}
\hline Groups & $\mathrm{N}$ & Average & St.Dev. & $\mathrm{t}$ & $\mathrm{sd}$ & $\mathrm{p}$ \\
\hline Lower Group & 28 & 4.32 & 1.416 & & & \\
Upper Groups & 28 & 13.07 & 1.980 & & & \\
\hline
\end{tabular}

As seen in Table 4, a significant difference was found between the upper and lower groups of the sample group, in which we performed the success test, in favor of the upper group $(\mathrm{p}<0.05)$. In this case, it can be said that the prepared test has the power to distinguish between the lower and upper groups in order to sub-meaning of the fraction. According to these results, it can be said that the test of success is good.

\subsubsection{Validity of Success Test}

The validity of a measuring instrument depends on the validity of each of the substances that make it. Substance discrimination indicates the validity coefficients of the substances in the test. In other words, matter discrimination is the coefficient that shows the extent to which the item measures the variable to be measured (Umay, 1997). According to Büyüköztürk et al. (2016), the validity is related to the extent to which the measurement tool measures the desired property of the individual without mixing with other characteristics.

In this context, scope, criterion and structure validity gain importance. Factor analysis (exploratory and confirmatory) was used to collect knowledge about the construct validity of the measurement tool. Factor analysis provides a significant contribution to the evaluation of the construct validity of the test scores (Nunnally, 1978; Stapleton, 1997, referring to Büyüköztürk et al., 2016, p. 119). One of the assumptions of the exploratory factor analysis is that the data are obtained at equal intervals and continuously. Since the scoring of the data in the prepared success test is " 1 " for the correct answers and " 0 " for the wrong answers, the correlation matrix that we should base on when we want to do an exploratory factor analysis should be the Polychoric (tetrachoric) correlation matrix (Lorenzo-Seva \& Van Ginkel, 2016). When it is desired to perform exploratory factor analysis for success tests, it is stated that a factor analysis based on tetrachoric correlation matrix should be performed (Lorenzo-Seva \& Ferrando, 2013). In this study, a factor analysis was performed based on the tetrachoric correlation matrix since a success test is prepared and correct-incorrectly evaluated for being coded. Factor analysis based on this tetrachoric correlation matrix was performed with a program called "Factor Analysis".

In order to determine the level of knowledge of the primary school teachers about the meaning of the fraction, the data obtained from the measurement tool consisting of open-ended questions were examined by Kaiser-Meyer Olkin (KMO) coefficient and Barlett Sphericity test.

Table 5. KMO and Bartlettlars test statistics for success test

\begin{tabular}{ccc}
\hline \multicolumn{2}{l}{ Kaiser-Meyer-Olkin Sample Eligibility Measure } & .832 \\
\hline & Approximate $\chi^{2}$ value & 660.225 \\
Bartlett sphericity test & Sd & 120 \\
& $\mathrm{p}$ & .000 \\
\hline
\end{tabular}

KMO test results cannot be accepted if they are less than $0.50 ; 0.50-0.60$ is bad value; $0.61-0.70$ is weak; $0.71-0.80$ medium; the value of 0.81-0.90 is good and the value above 0.90 is reported to be excellent (Çokluk, Şekercioğlu, \& Büyüköztürk, 2012; Şencan, 2005). The KMO coefficient indicates that the data are suitable for analysis as it approaches 1, and that it is a perfect fit when it is 1 (Sharma, 1996, p. 116). It can be said that the KMO test result, which was performed to determine whether this test is suitable for factor analysis, is well-suited to the fact that it is 
0.832. The data shows that comes from a multivariate normal distribution because the chi-square $\left(\chi^{2}\right)$ test statistics obtained as a result of this test were significant $(\mathrm{p}<0.05)$.

Eigenvalue and variance percentages can be used to determine the number of factors that can reveal the relationship between substances (Çokluk et al., 2012). The rotated basic components analysis was performed for the prepared success test. The principal component analysis describes how a variable will contribute to the component and the state of the existing components in the data (Field, 2002). The following table shows the eigenvalue, the explained variance and the total explained variance percentages.

In the table 6 , the results of the exploratory factor analysis of the success test prepared for sub-meaning of the fractions are seen. For the 16-items test for success test, five components with eigenvalue above 1 formed. In the content of these components, it is seen that $24.82 \%$ of the total variance by the first component, $10.12 \%$ by the second, $8.87 \%$ by the third, $7.40 \%$ by the fourth and $6.35 \%$ by the fifth component is explained. The total explained variance was rate of $57.56 \%$. Factor loads are very important in calculating the variance rate explained by each factor and are the coefficients used to decide the number of factors. As the eigenvalue increases, the variance explained by the factor increases (Tabachnick \& Fideli, 2001 from transferred Büyüköztürk, 2002). The factors and question values of the questions of the success test for sub-meaning of the fractions are below.

Table 6. Total variance description of the success test for the meaning of fractions

\begin{tabular}{cccc}
\hline \multirow{2}{*}{ Components } & \multicolumn{3}{c}{ Total Factor Loads (Rotated) } \\
\cline { 2 - 4 } & Eigenvalue & Explained Variance (\%) & Total Variance (\%) \\
\hline 1 & 3.971 & 24.82 & 24.82 \\
2 & 1.620 & 10.12 & 34.94 \\
3 & 1.420 & 8.87 & 43.81 \\
4 & 1.184 & 7.40 & 51.21 \\
5 & 1.008 & 6.35 & 57.56 \\
\hline
\end{tabular}

After determining the factor number of the success test, the distribution of the item to the factors was examined. The rotated component matrix is formed to determine which factor is in strong correlation. According to this, the acceptance levels of the items' aggregation and factor load values are shown in Table 7.

Table 7. Factor pattern of the success test for sub-meaning of the fractions (Vertical rotation-varimax)

\begin{tabular}{|c|c|c|c|c|c|}
\hline \multirow{2}{*}{ Questions } & \multicolumn{5}{|c|}{ Components } \\
\hline & 1 (Part-whole) & 2 (Quotient) & 3 (Operator) & 4 (Measure) & 5 (Ratio) \\
\hline Question 1 & 0.620 & & & & \\
\hline Question 3 & 0.513 & & & & \\
\hline Question 4 & 0.458 & & & & \\
\hline Question 5 & 0.446 & & & & \\
\hline Question 9 & & 0.677 & & & \\
\hline Question 10 & & 0.689 & & & \\
\hline Question 11 & & 0.576 & & & \\
\hline Question 14 & & & 0.854 & & \\
\hline Question 15 & & & 0.383 & & \\
\hline Question 16 & & & 0.650 & & \\
\hline Question 12 & & & & 0.997 & \\
\hline Question 7 & & & & 0.493 & \\
\hline Question 13 & & & & 0.706 & 0.685 \\
\hline Question 6 & & & & & 0.851 \\
\hline Question 8 & & & & & 0.388 \\
\hline Question 2 & & & & & 0.358 \\
\hline
\end{tabular}

For a items' aggregation, the level of acceptance of an item in more than one factor must give a high load value or the load values of two or more factors of the item should be less than 0.1 (Çokluk et al., 2012, p. 233). In the exploratory factor analysis conducted to reveal the factor design of the success test prepared for the primary school 
teachers towards the meanings of the fraction, the acceptable factor load value was accepted as 0.30 . Question 13 gives a load value of 0.706 in factor 4 and 0.685 in factor 5 . The value of this item in both factors is greater than the acceptable load value of 0.30 and the difference between these two load values $(0.706-0.685=0.021)$ is smaller than 0.1 ; indicating that this item is distributed to both types of questions. In exploratory factor analysis, aggregation is undesirable. However, since the test of success was a test prepared for the meanings of the fraction and the meanings of fractions are not definitively and clearly differentiated, it was assumed appropriate not to remove the question 13 by taking expert opinion.

According to the results of exploratory factor analysis, in the success test prepared for the sub-meaning of the fractions, factor 1 means the part-whole of the fraction; factor 2 means quotient of the fraction; factor 3 means the operator of the fraction; factor 4 means measure of the fraction and factor 5 means the ratio of the fraction

The reliability values of five sub-dimensions of the success test prepared for the sub-meanings of the fraction are given below.

Table 8 . The reliability values of five sub-dimensions of the success test

\begin{tabular}{lccc}
\hline Components of Success Test & Number of Items & Variance of Component & Reliability Value (KR-20) \\
\hline Fraction part-whole meaning dimension & 4 & 1.026 & 0.760 \\
Fraction quotient meaning dimension & 3 & 1.638 & 0.759 \\
Fraction operator meaning dimension & 3 & 1.572 & 0.805 \\
Fraction measure meaning dimension & 3 & 1.194 & 0.995 \\
Fraction ratio meaning dimension & 3 & 1.244 & 0.764 \\
\hline
\end{tabular}

In the success test, the reliability value (KR-20) of quotient sub-meaning of the fractions was found to be the lowest with a value of 0.759 , and the reliability value (KR-20) of measure sub-meaning of the fractions with 0.995 was the highest. The reliability of each component of the test can be said to be good. It is also accepted that the KR-20 reliability coefficient is high and it also gives information about structure validity (Büyüköztürk et al., 2016). Accordingly, it can be said that the construct validity of the success test is high.

\subsection{The Process of Application}

The achievement test was applied to the primary school teachers in the second semester of the academic year 2017-2018. Each class teacher was briefed on the achievement test before practicing. Success test was applied to each teacher individually and the teachers were not affected from each other. Teachers participated in various provinces of Turkey. Among these, there is a province from the eastern Mediterranean region, a province from the central Anatolia region and a province from the marmara region.

\subsection{Data Analysis}

The answers to the success test which consists of 16 open-ended questions about the meaning of the fraction, which is a quantitative data collection tool, were evaluated according to their true and false. In this evaluation, the answers given to each question were coded if true, 1 and if false, 0 . because the questions consist of open-ended questions. Data were analyzed by using SPSS 21 package program. The normal distribution of the data was analyzed and the according to the data obtained, results were analyzed. While evaluating the obtained data, values such as percentage, frequency, arithmetic mean and standard deviation from descriptive statistical methods were used. Pearson correlation analysis, which is used in the data of normal distribution, was used for the relationship between the different meanings of the fraction in the answers of the primary school teachers.

\section{Findings}

The first problem of this research that "What is knowledge of primary school teachers about the general meaning of the fraction?" in order to find an answer to the question, the success test was applied. The statistics of the answers given by the primary school teachers for the success test are given in the table below. 
Table 9. Statistics of the answers given by the primary school teachers to the success tests about the general meaning of the fraction

\begin{tabular}{|c|c|c|c|c|c|c|c|c|c|}
\hline Questions & \multicolumn{2}{|c|}{ True } & \multicolumn{2}{|c|}{ False } & Questions & \multicolumn{2}{|c|}{ True } & \multicolumn{2}{|c|}{ False } \\
\hline \multirow{2}{*}{ Question 1} & $(\mathrm{~N})$ & 224 & $(\mathrm{~N})$ & 42 & \multirow{2}{*}{ Question 9} & $(\mathrm{~N})$ & 130 & $(\mathrm{~N})$ & 136 \\
\hline & $(\%)$ & 84.2 & $(\%)$ & 15.8 & & $(\%)$ & 48.9 & $(\%)$ & 51.1 \\
\hline \multirow{2}{*}{ Question 2} & $(\mathrm{~N})$ & 180 & $(\mathrm{~N})$ & 86 & \multirow{2}{*}{ Question 10} & $(\mathrm{~N})$ & 130 & $(\mathrm{~N})$ & 136 \\
\hline & $(\%)$ & 67.7 & $(\%)$ & 32.3 & & $(\%)$ & 48.9 & $(\%)$ & 51.1 \\
\hline \multirow{2}{*}{ Question 3} & $(\mathrm{~N})$ & 165 & $(\mathrm{~N})$ & 101 & \multirow{2}{*}{ Question 11} & $(\mathrm{~N})$ & 149 & $(\mathrm{~N})$ & 117 \\
\hline & $(\%)$ & 62.0 & $(\%)$ & 38.0 & & $(\%)$ & 56.0 & $(\%)$ & 44.0 \\
\hline \multirow{2}{*}{ Question 4} & $(\mathrm{~N})$ & 204 & $(\mathrm{~N})$ & 62 & \multirow{2}{*}{ Question 12} & $(\mathrm{~N})$ & 174 & $(\mathrm{~N})$ & 92 \\
\hline & $(\%)$ & 76.7 & $(\%)$ & 23.3 & & $(\%)$ & 65.4 & $(\%)$ & 34.6 \\
\hline \multirow{2}{*}{ Question 5} & $(\mathrm{~N})$ & 134 & $(\mathrm{~N})$ & 132 & \multirow{2}{*}{ Question 13} & $(\mathrm{~N})$ & 93 & $(\mathrm{~N})$ & 173 \\
\hline & $(\%)$ & 50.4 & $(\%)$ & 49.6 & & $(\%)$ & 35.0 & $(\%)$ & 65.0 \\
\hline \multirow{2}{*}{ Question 6} & $(\mathrm{~N})$ & 118 & $(\mathrm{~N})$ & 148 & \multirow{2}{*}{ Question 14} & $(\mathrm{~N})$ & 215 & $(\mathrm{~N})$ & 51 \\
\hline & $(\%)$ & 44.4 & $(\%)$ & 55.6 & & $(\%)$ & 80.8 & $(\%)$ & 19.2 \\
\hline \multirow{2}{*}{ Question 7} & $(\mathrm{~N})$ & 167 & $(\mathrm{~N})$ & 99 & \multirow{2}{*}{ Question 15} & $(\mathrm{~N})$ & 210 & $(\mathrm{~N})$ & 56 \\
\hline & $(\%)$ & 62.8 & $(\%)$ & 37.2 & & $(\%)$ & 78.9 & $(\%)$ & 21.1 \\
\hline \multirow{2}{*}{ Question 8} & $(\mathrm{~N})$ & 114 & $(\mathrm{~N})$ & 152 & \multirow{2}{*}{ Question 16} & $(\mathrm{~N})$ & 210 & $(\mathrm{~N})$ & 56 \\
\hline & $(\%)$ & 42.9 & $(\%)$ & 57.1 & & $(\%)$ & 78.9 & $(\%)$ & 21.1 \\
\hline
\end{tabular}

Primary school teachers gave the most correct answer to the first question $(84.2 \%)$ and the least correct answer was the 13th question (35\%). The competence of the level of learning was expressed as $75 \%$ of the full learning of the material applied in a micro study measured by the success test (Yildıran, 1982). According to this, it can be said that the primary school teachers have enough knowledge about the exact learning only 1st question, the 4th question, the 14th question, the 15th question and the 16th question. It was concluded that only five questions were above the level of exact learning in the 16-item success test for primary school teachers. Less than half of the primary school teachers were able to answer correctly for 6th question, 8th question, 9th question, 10th question and 13th question. It was concluded that the answers given to these five questions were below $50 \%$ and they were at very low levels compared to the exact learning approach.

In addition, the overall success average of the primary school teachers participating in the study was calculated as 60.2 points. Considering that the difficulty level of the success test is 0.55 , it can be said that the average score of the primary school teachers in terms of the mean of the scores is moderate. However, it is possible to say that the average success test was insufficient when it was considered that the prepared success test was prepared in question types and content related to the fraction subjects in the range of 4-8 grade.

The second sub-problem of this research is "What is the knowledge of the primary school teachers about each sub-meaning of the fraction?" The answers of the primary school teachers for the success test prepared for the meanings of the fraction were examined according to the sub-meanings of the fraction. The statistics of the answers given by the primary school teachers to the questions about each sub-meaning of the fraction in the success test are given in Table10 below.

Table 10. Knowledge levels of primary school teachers for each sub-meaning of the fraction

\begin{tabular}{lccccc}
\hline Sub-meaning of Fractions & $\mathrm{N}$ & $\mathrm{X}$ & Variance & Lower Group Points & Upper Group Points \\
\hline Part-Whole & 266 & 0.68 & 0.074 & 0.65 & 0.72 \\
Operator & 266 & 0.80 & 0.081 & 0.76 & 0.83 \\
Measure & 266 & 0.54 & 0.108 & 0.50 & 0.58 \\
Ratio & 266 & 0.48 & 0.085 & 0.44 & 0.51 \\
Quotient & 266 & 0.51 & 0.148 & 0.47 & 0.56 \\
\hline
\end{tabular}

*Averages are given as 0.68 because they are considered as percentage.

When the table is examined, it is seen that the average of the scores of the primary school teachers from success test prepared for the five different meanings of the fraction. The mean score for the part-whole of the fraction was 0.68 ; the lower group score was 0.65 ; the upper group score was 0.72 and the variance was 0.074 . The mean score for the operator (processor) sub-meaning of the fraction was 0.80 ; the lower group score was 0.76 ; the upper group 
score was 0.83 and the variance was 0.081 . The mean score for the measure sub-meaning of the fraction was 0.54 , the lower group score was 0.50 ; the upper group score was 0.58 and the variance was 0.108 . The mean score for ratio sub-meaning of the fraction was 0.48 ; the lower group score was 0.44 ; the upper group score was 0.51 and the variance was 0.085 . In addition, the mean score of the quotient (division) sub-meaning of the fraction was 0.51 ; the lower group score was 0.47 ; the upper group score was 0.56 and the variance was 0.148 . There was also a difference of at least 7 percent and a maximum of 9 percent among the upper and lower group scores.

According to these results, it is seen that the most accurate answer to the questions about the meaning of the operator and the least correct answer to the questions related to the meaning ratio of the fraction. The reason for the correct answer to the questions in the meaning operator of the fraction is that both the curricula in the curriculums are "the finding the desired fraction of a muchness" and the teaching processes are given more process-oriented. The reason for the fact that the part-whole meaning of the fraction is above the average of 0.68 may be due to the fact that the most known and applied meaning of the fraction is the part-whole. It is observed that primary school teachers have scores below the average in the other three sub-meanings of the fraction, rate, quotient (division) and measure. The reason for this situation may be the fact that the concepts of ratio, quotient and measure are included in the curriculum in separate subjects and topics and these are not given by relating to each other and the concept of fraction.

The third sub-problem of this research is "What is the relationship between the primary school teachers' knowledge for the different meanings of the fraction?". In order to find an answer to this question, the relationship between the answers of each sub-meaning of the fraction and the success test prepared for the meanings of the fraction was examined. Pearson correlation analysis that used for the relationship between normal distribution data was used to determine the relationship between the level of knowledge of the primary school teachers for different meanings of the fraction. When looking at the relationship between the variables, if the variables are together increasing and together decreasing values, they are positive; If one of the variables increases and the other decreases, the relationship is negative. And the relationship quantity is determined by the correlation coefficient (Karasar, 2012).

The results of the Pearson correlation analysis of the answers to the questions about the sub-meanings of the fraction in the success test applied to 266 primary school teachers are given in Table 11.

Table 11. Pearson correlation results of teachers' knowledge of levels in different meanings of fractions

\begin{tabular}{ccccccccc}
\hline Sub-meaning of & \multicolumn{2}{c}{ Part-Whole } & \multicolumn{2}{c}{ Operator } & \multicolumn{2}{c}{ Measure } & \multicolumn{2}{c}{ Ratio } \\
\cline { 2 - 9 } Fractions & $\mathrm{r}$ & $\mathrm{p}$ & $\mathrm{r}$ & $\mathrm{p}$ & $\mathrm{r}$ & $\mathrm{p}$ & $\mathrm{r}$ & $\mathrm{p}$ \\
\hline Operator & $.352^{*}$ & .000 & - & - & - & - & - & - \\
Measure & $.419^{*}$ & .000 & $.331^{*}$ & .000 & - & - & - & - \\
Ratio & $.392^{*}$ & .000 & $.259^{*}$ & .000 & $.619^{*}$ & .000 & - & - \\
Quotient & $.363^{*}$ & .000 & $.309^{*}$ & .000 & $.444^{*}$ & .000 & $.575^{*}$ & .000 \\
\hline
\end{tabular}

As shown in the table, Pearson correlation values used for parametric tests show that each meaning of the fraction is in a meaningful relationship with each other. It can be said that the answers given to the part-whole meaning of the fraction are in the positive direction with the other meanings of the fraction and the mean correlation value is in the medium level $(\mathrm{r}=+0.51)$. It is seen that the answers given to the operator meaning of the fraction are in a positive way with the other meanings of the fraction and have a weak relationship with the mean correlation value $(\mathrm{r}=+0.45)$. The answers given to the measure meaning of the fraction are in a positive relationship with the other meanings of the fraction and have a moderate relationship because the mean correlation value is average $(\mathrm{r}=+$ 0.56). The answers given to the ratio meaning of the fraction are in a positive way with the other meanings of the fraction and have a moderate relation with the mean correlation value $(\mathrm{r}=+0.57)$. Again, it is possible to say that the answers given to the quotient (division) meaning of the fraction are in the positive direction with the other meanings of the fraction, and that the mean correlation value $(r=+0.54)$ is in the intermediate level. Because the correlation coefficient will not give knowledge about why such a relationship exists or will not give knowledge about the cause-effect relationship (Ünal, 1996, s.171), the correlation between responses of the primary school teachers for each sub-meaning of the fraction can be said that each meaning of the fraction has a meaningful relationship with the other meanings $(\mathrm{p}<0.05)$ and these relationships are a positive relationship between low and medium level. For example, it can be said that a student who understands the measure meaning of the fraction is able to understand the ratio meaning of the fraction. Or, it can be concluded that a student who knows the ratio meaning of the fractional has information about the quotient meaning of the fraction. Because, there is a 
connection between these meanings of the fraction.

\section{Conclusion and Discussion}

In this study, a success test was applied to measure the knowledge of the primary school teachers about the meaning of the fraction. The overall average of the answers given by the primary school teachers for the success test was 60.2 points. Considering that the difficulty level of the success test applied is 0.55 , it can be said that the average score of the primary school teachers for the sub-meaning of the fraction is not enough. Because there is no point that can be accepted as high enough for a success test which is not a high level of difficulty.

This result is very close to the score obtained in the study of Doğan and Tertemiz (2018) for primary school teacher candidates and the meaning of the fraction (59.7\%). Similarly, Newton (2008) reported that the success rate of the primary school teacher candidates is about $70 \%$ in their study on knowledge of basic fraction concepts and their ability to solve verbal problems related to fractions. Van Steenbrugge et al. (2014) primary school teacher candidates in the study of fractional knowledge, according to the general meaning of the fraction, the level of knowledge of the primary school teacher candidates was $82 \%$. Even though the scores obtained from the studies conducted on prospective teachers are higher than the findings at hand, in studies conducted on students at different levels are also supporting the results of the present study. Baker et al. (2012) examined the fractional knowledge of adults and conducted this study with 333 university students, the performance of adults for fraction questions was $55.7 \%$. Doyle et al. (2016) study about relationship between the sub-meaning of the fractions and the problem solving with high school students, they have achieved success with $61.4 \%$ in terms of the meaning of the fraction. Similarly, Clarke et al. (2011) work with the way interviewed by sixth grade students, students' conceptual and operational success in the fractions reached the conclusion that the level of $42.8 \%$. In the study conducted by Charalambous and Pitta-Pantazi (2007) with 646 fifth and sixth grade students, they were found that the students' knowledge about fractions was $52.8 \%$. When the findings obtained from these studies are examined, it is seen that the studies conducted for students, teacher candidates, teachers or adults are not in a good condition in terms of fraction and support the findings obtained in this study.

In general, it is emphasized in many studies that both teacher and teacher candidates who teach both this concept and the students who no matter what level are not in a good condition (Ball, 1990; Gökkurt vd., 2015; Işıksal, 2006; Karaağaç \& Köse, 2015; McDiarmid \& Ball, 1989; Mumcu, 2017; Toluk-Uçar, 2011). It can be considered that a teacher who does not have sufficient knowledge of the field will not be able to develop the pedagogical content knowledge in the subject. According to this, it can be said that if the primary school teachers do not have sufficient knowledge about the fraction, teaching the fraction subject to the students will not be successful. For this purpose, planning of teaching processes by focusing on the sub-meanings of both the conceptual and the operative in the process of education of the primary school teachers can help these teachers to realize more effective teaching processes.

When the average of the points taken from the success test for the five different sub-meanings of the primary school teachers is examined, it is seen that the score of the operator (processor) sub-meaning of the fraction is the highest score of $80 \%$. This is followed by part-whole (68\%), measure (54\%), quotient (division) (51\%) and ratio (48\%), respectively.

The most accurate answer was found in the part-whole sub-meaning of the fraction with $85 \%$ in the study conducted by Doğan and Tertemiz (2018) in order to examine the level of knowledge about the five meanings the fraction of the teacher candidates. This was followed by $67 \%$ of the meaning ratio of the fraction, $63 \%$ of the meaning operator (processor) of the fraction, $47 \%$ of the meaning measure of the fraction, and $36 \%$ of the meaning quotient (division) of the fraction. Compared to this study, it can be said that both the part-whole and the operator (processor) meanings of the fractions are higher than the other meanings of the fractions. The reason for this is that the elementary mathematics teaching program (MEB, 2015), even at different class levels, is more concerned with the part-whole meanings of the fractions and then the operator (processor) meanings of the fractions. Considering the fact that the ratio and quotient (division) meanings of the fraction are mostly included in the Secondary School Mathematics Curriculum (MEB, 2013), it can be said that because the primary school teachers mostly concentrate their own programs, they overlook other meanings of the fraction. In addition, it can be explained that the meaning of measure and ratio of the fraction is not known enough as the meaning of the fraction in the curriculum, because they are separate and independent subjects apart from the fraction. The reason for the lower meaning of quotient (division) according to the other meanings of the fractions may be due to the fact that the teaching programs are not much mentioned and the numerical values that are expressed by the fractions are not emphasized.

Van Steenbrugge et al. (2014), reported that the level of knowledge about the ratio meaning of the fraction of the primary school teacher candidates was found to be $94 \%$, the level of knowledge about the part-whole meaning of 
the fraction was found to be $90 \%$, the level of knowledge about the quotient (division) meaning of the fraction was found to be $81 \%$, the level of knowledge about the operator (processor) meaning of the fraction was found to be $78 \%$ and the level of knowledge about the measure meaning of the fraction was found to be $66 \%$. When these results are compared with the results of our research, it is possible to see very different results according to the meanings of the fraction. For example, while the level of knowledge of the primary school teacher candidates has the highest rate meanings of the fraction in this study, it is seen that the primary school teachers in the study show the least success.

Baker et al. (2012) in the study of adult students in terms of success for the sub-meanings of the fractions, it was seen that parts-whole meaning of the fraction $67 \%$; operator (processor) meaning of the fraction $53 \%$ and measure meaning of the fraction $47 \%$. In this study, there is no study on the ratio and quotient sub-meanings of the fractions. However, the success rates according to the meanings of the findings obtained for other meanings of the fractions are similar to the success rates in our study.

Similarly, Doyle et al. (2016), according to the findings obtained from high school students, the success rate for part-whole meaning of the fraction is $74 \%$. The rate of success for the ratio meaning of the fraction was calculated as $67 \%$, the success rate for the operator (processor) meaning of the fraction was $62 \%$, the success rate for the quotient meaning of the fraction was $55 \%$ and the success rate for the measure meaning of the fraction was $49 \%$. There are many differences between the findings obtained from this study and the findings in the present study. For example, while the ratio meaning of the fraction is the second most important in study of Doyle et al, it was the lowest level of knowledge in the study. This difference between the sub-meanings of the fraction may have been caused by the differences of the groups in which the study was conducted. Because one of the studies was conducted with teachers and the other with high school students. This difference can also be expected when the measurement tools used to measure successes are different

Clarke et al. (2011) in his study with sixth grade students, according to the responses from the students, the success for operator meaning of the fraction was $64.5 \%$; success for measure meaning was $51.1 \%$; success for quotient meaning was $30.3 \%$ and success for part-whole meaning was $25.4 \%$ in the sense of achieving success. In addition, there are no conclusions regarding the ratio meaning of the fraction in this study. In this study, the success of the whole part of the fraction in the last place is in conflict with the findings of this study. Other than this, the success rates and values of this study are in parallel with present study.

In the study carried out by Charalambous and Pitta-Pantazi (2007) with fifth and sixth grade students, the results of the fraction were $75 \%$ in terms of part-whole, $64 \%$ in terms of ratio, $55 \%$ in terms of quotient (division), $45 \%$ in terms of operator (processor) and 25\% in terms of measure. When compared to the findings of this research, it is seen that the success of each meaning of the fraction changes. The results obtained from these studies are comparatively given in Table 12 below.

Table 12. Findings from the studies conducted for sub-meanings of the fraction

\begin{tabular}{ccccccc}
\hline & Working group & Part-Whole & Operator & Ratio & Measure & Quotient \\
\hline Findings of this Research & Primary School Teachers & 68 & 80 & 48 & 54 & 51 \\
Doğan ve Tertemiz (2018) & Teachers Candidates & 85 & 63 & 67 & 47 & 36 \\
Doyle vd. (2016) & High School Students & 74 & 62 & 67 & 49 & 55 \\
Van Steenbrugge vd. & Teachers Candidates & 90 & 78 & 94 & 66 & 81 \\
(2014) & Adult Students & 67 & 53 & $-*$ & 47 & $-*$ \\
Baker vd. (2012) & 6th Grade Students & 25 & 65 & $-*$ & 51 & 30 \\
Clarke vd. (2011) & 5th and 6th Grade Students & 75 & 45 & 64 & 25 & 55 \\
Charalambous ve & & & & \\
Pitta-Pantazi (2007) & &
\end{tabular}

*indicated no evidence of any findings related to the meaning of the fraction.

In the studies conducted at different groups and grades on the success levels of the teachers in terms of the meaning of the fraction, it is observed that there are studies that support the work at hand and that there are studies in the opposite direction. In other words, in studies conducted at different groups and grades, the levels of knowledge about the different meanings of the fraction show changes. This may be due to the fact that the study was carried out on different groups and it was surveyed with different measurement tools.

The Pearson correlation coefficient was examined in order to look at the relationship between the primary school 
teachers' knowledge for the different meanings of the fraction. According to Pearson correlation values, it was concluded that each meaning of the fraction is in a meaningful relationship with each other. It is concluded that while the operator meaning of the fraction has a weak relationship with the other meanings of the fraction, the part-whole, measure, ratio and quotient meanings of the fraction has a moderate relationship with the other meanings of the fraction. Moreover, all of the relationships between the meanings of these were found to be positive. These findings support the findings of some previous studies (Doyle et al., 2016; Gabriel, Coché, Szucs, Carette, Rey \& Content, 2013; Charalambous \& Pitta-Pantazi, 2007).

However, Van Steenbrugge et al. (2014) in the study of the conceptual and procedural fractional knowledge of the primary school teacher candidates in contrast to the findings obtained in this study, it is concluded that the candidates of the primary school teachers have a negative correlation between part-whole meaning of the fraction with ratio meaning of the fraction and a positive correlation with the other meanings of the fraction. The operator meaning of the fraction is also negatively correlated with the splitting meaning; among all the other meanings of the fraction, a positive correlation was found to be similar to the findings in this study. At this point, it is seen that primary school teacher candidates with primary school teachers have negative correlation between part-whole meaning with ratio meaning and also between operators meaning with quotient meaning, these situations are different with this study. Because, in this study, there is a positive relationship between all the meanings of the fraction.

\subsection{Suggestions}

Teachers' subject matter knowledge and how the profound understanding of fundamental mathematics is attained are discussed. For example; American teachers are offered no opportunities within the school day for these collaborative deliberations, therefore can teach for many years without deepening their understandings of the content they teach. But Chinese teachers continue to learn mathematics and to refine their content understandings throughout their teaching careers. Teachers' work in China includes time and support for serious deliberations and seminars on the content of their lessons (Ma, 2010). Efforts constantly to keep open to learning about issues of class teachers in Turkey would be appropriate like to Chinese. The following may be recommended for improvement:

1) It is advised for the primary school teachers to know the knowledge about the fraction, the knowledge of the sub-meanings of the fraction and the relations between the meanings of the fraction. Because this is pedagogically important.

2) This issue may be given at the undergraduate level in order to increase the knowledge of the class teachers about the fraction.

3) The primary school teachers have sufficient knowledge about the meanings of the fraction and their use in the applications of the education process is considered important in terms of the quality of teaching. Therefore, it can be suggested to plan the teaching process by considering the fractional subject in terms of both conceptual and operational.

\section{References}

Akar, G. K. (2014). Oran konusunun kavramsal öğretiminde karşılaşılan zorluklar ve çözüm önerileri [Difficulties and solutions for conceptual teaching of rate]. In E. Bingölbali, \& M. F. Özmantar (Eds.), Matematiksel zorluklar ve çözüm önerileri (pp. 263-285). Ankara: Pegem Akademi. https://doi.org/10.14527/9786053188094.04

Aksu, M. (1997). Students performance dealing with fractions. The Journal of Educational Research, 90(6), 375-380. https://doi.org/10.1080/00220671.1997.10544595

Altun, M. (2013). Ortaokullarda (5, 6, 7 ve 8. sinfflarda) matematik ögretimi [Teaching mathematics in secondary schools (grades 5, 6, 7 and 8)] (9th ed.). İstanbul: Alfa Aktüel.

Arcavi, A. (2003). A role of visual representations in the learning of mathematics. Educational Studies in Mathematics, 52(3), 215-241. Retrieved from http://cimm.ucr.ac.cr/ojs/index.php/eudoxus/article/viewFile/ $154 / 152$

Bademci, V. (2011). Kuder-Richardson 20. Cronbach'ın Alfası, Hoyt'un varyans analizi, genellenirlik kuramı ve ölçüm güvenirliği üzerine bir çalışma [A Study on the Kuder-Richardson 20. Cronbach's Alpha, Hoyt's Analysis of Variance, Generalizability Theory and Score Reliability]. Dicle Üniversitesi Ziya Gökalp Ĕgitim Fakültesi Dergisi [Dicle University, Ziya Gökalp Faculty of Education Journal], 17, 173-193. https://doi.org/10.14582/duzgef.674 
Baker, W. J., Czarnocha, B., Dias, O., Doyle, K., \& Kennis, J. R. (2012). Procedural and conceptual knowledge: adults reviewing fractions. Adults Learning Mathematics, 7(2), 39-65. Retrieved from https://files.eric.ed.gov/fulltext/EJ1068220.pdf

Ball, D. L. (1990). The mathematical understandings that prospective teachers bring to teacher education. Elementary School Journal, 90, 449-466. https://doi.org/10.1086/461626

Ball, D. L., Hill, H. H., \& Bass, H. (2005). Knowing mathematics for teaching: Who knows mathematics well enough to teach third grade, and how can we decide? American Educator, 2, 14-46. Retrieved from $\mathrm{http}: / /$ hdl.handle.net/2027.42/65072

Baloğlu, N. (2001). Etkili sinıf yönetimi [Effective classroom management]. Ankara: Baran.

Baykul, Y. (2005). Ilköğretimde matematik öğretimi (1-5.sinfflar için) [Teaching mathematics in primary education (for grades 1-5)]. Ankara: Pegem A.

Behr, M., Harel, G., Post, T., \& Lesh, R. (1993). Rational numbers: Toward a semantic analysis-emphasis on the operator construct. In T. Carpenter, E. Fennema, \& T. Ramberg (Eds.), Rational numbers: An integration of research (pp. 13-47). Hillsdale, New Jersey: Lawrence Erlbaum.

Bezuk, N. S., \& Armstrong, B. E. (1993). Understanding division of fractions. The Mathematics Teacher, 86(1), 43-46.

Biber, A. Ç., Tuna, A., \& Aktaş, O. (2013). Öğrencilerin kesirler konusundaki kavram yanılgıları ve bu yanılgıların kesir problemleri çözümlerine etkisi [Students' Misconceptions of Fractions and its Effect on Solving Fractions Problem]. Trakya Üniversitesi Eğitim Fakültesi Dergisi [Trakya University Faculty of Education Journal], 3(2), 152-162. https://doi.org/10.17556/jef.30116

Bloom, B. S. (1976). Human characteristics and school learning. New York: McGraw-Hill.

Booker, G. (1998). Children's construction of initial fraction concepts. In Proceedings of the 22nd Conference of the International Group for the Psychology of Mathematics Education, 2, 128-135. Retrieved from https://files.eric.ed.gov/fulltext/ED427970.pdf\#page=136

Bray, W. S., \& Abreu-Sanchez, L. (2010). Using number sense to compare fractions. Teaching Children Mathematics, 17, 90-97. Retrieved from https://eric.ed.gov/?id=EJ898233

Brown, G., \& Quinn, R. (2006). Algebra students' difficulty with fractions: An error analysis. Australian Mathematics Teacher, 62(4), 28-40. Retrieved from https://files.eric.ed.gov/fulltext/EJ765838.pdf

Bursalığlu, Z. (2002). Okul yönetiminde yeni yapı ve davranış [New structure and behavior in school management]. Ankara. Pegem A.

Büyüköztürk, Ş. (2002). Faktör analizi: Temel kavramlar ve ölçek geliştirmede kullanımı [Factor analysıs: Basic concepts and using to development scale]. Educational sciences: Theory \& practice, 32(32), 470-483. Retrieved from http://www.kuey.net/index.php/kuey/article/view/517

Büyüköztürk, Ş., Kılıç-Çakmak, E., Akgün, Ö. E., Karadeniz, Ş., \& Demirel, F. (2016). Bilimsel araştırma yöntemleri [Scientific research methods (Extended 21st Edition)]. Ankara. Pegem Akademi. https://doi.org/10.14527/9789944919289

Charalambous, C. Y. \& Pitta-Pantazi, D. (2007). Drawing on a theoretical model to study students' understandings of fractions. Educational Studies in Mathematics, 64(3), 293. https://doi.org/10.1007/s10649-006-9036-2

Charalambous, C. Y., \& Pitta-Pintazi, D. (2005). Revisiting a theoretical model on fractions: implications for teaching and research. In Chick, H. L. \& Vincent, J. L. (Ed.), Proceedings of the 29th Conference of the International Group for the Psychology of Mathematics Education, (pp.233-240). Melbourne.

Chase, C. I. (1999). Contemporary assessment for educators. New York: Longman.

Clarke, D., Roche, A., \& Mitchell, A. (2011). One-to-one student interviews provide powerful insights and clear focus for the teaching of fractions in the middle years. In J. Way, \& J. Bobis (Eds.), Fractions: Teaching for understanding (pp. 23-31). Australia: Australian Association of Mathematics Teachers.

Cohen, L., Manion, L., \& Morrison, K. (2000). Research methods in education. New York: Routledge Falmer.

Çokluk, Ö., Şekercioğlu, G., \& Büyüköztürk, Ş. (2012). Sosyal bilimler için çok değişkenli istatistik: SPSS ve lisrel uygulamalarl [Multivariate statistics for social sciences: SPSS and lisrel applications]. Ankara: Pegem Akademi. https://doi.org/10.14527/9789756802335 
Crocker, L. M., \& Algina, J. (1986). Introduction to classical and modern test theory. New York: Holt, Rinehart and Winston.

Doğan, A., \& Tertemiz, N. (2018) Sınıf Öğretmeni adaylarının kesrin anlamlarına yönelik bilgi düzeylerinin incelenmesi [Examination of knowledge levels of primary school teacher candidates to fractional meanings]. The Journal of Academic Social Science, 68, 580-597. https://doi.org/10.16992/asos.13582

Doyle, K. M., Dias, O., Kennis, J. R., Czarnocha, B., \& Baker, W. (2016). The rational number sub-constructs as a foundation for problem solving. Adults Learning Mathematics, 11(1), 21-42. Retrieved from https://files.eric.ed.gov/fulltext/EJ1091996.pdf

Ekiz, D. (2011). Primary school teachers' preactive teaching and practical theories. Germany: Lambert Academic.

Erkuş, A. (2003). Writing on psychometry: Historical roots of measurement and psychometry, reliability, validity, substance analysis, attitudes; Components and measurement. Ankara: Turkish Psychologists Association.

Ersoy, Y. (2003). Teknoloji destekli matematik eğitimi-l: Gelişmeler, politikalar ve stratejiler [Technology supported mathematics education-1: Developments, policies and strategies]. Elementary Education Online, 2(1), 18-27.

Field, A. (2002). Discovering Statistics Using SPSS. Sage Publications. UK: London.

Flores, A., Samson, J., \& Yanik, H. B. (2006). Quotient and measurement interpretations of rational numbers. Teaching Children Mathematics, 13, 34-39.

Gabriel, F. C., Coché, F., Szucs, D., Carette, V., Rey, B., \& Content, A. (2013). A componential view of children's difficulties in learning fractions. Frontiers in Psychology, 4, 715-730. https://doi.org/10.3389/fpsyg.2013.00715

Gökkurt, B., Soylu, Y., \& Demir, Ö. (2015). Ortaokul matematik öğretmenlerinin kesirlerin öğretimine yönelik görüşlerinin incelenmesi [Examining the opinions of secondary mathematics teachers on teaching fractions]. Necatibey Eğitim Fakültesi Elektronik Fen ve Matematik Eğitimi Dergisi [Necatibey Faculty of Education Electronic Journal of Science and Mathematics Education], 9(2), 1-25. https://doi.org/10.17522/nefefmed.23191

Grove, S. K., Burns, N., \& Gray, J. (2012). The practice of nursing research: Appraisal, synthesis, and generation of evidence. Elsevier Health Sciences.

Gür, H., \& Korkmaz, E. (2003). İlköğretim 7. sinı öğrencilerinin problem ortaya atma becerilerinin belirlenmesi [Determining problem solving skills of 7th grade students]. Retrieved from http://www.matder.org.tr/index.php?option=com_content\&view=article \&id=61

Hasemann, K. (1981). On difficulties with fractions. Educational Studies in Mathematics, 12(1), 71-87. https://doi.org/10.1007/BF00386047

Işık, C. (2011). İlköğretim matematik öğretmeni adaylarının kesirlerde çarpma ve bölmeye yönelik kurdukları problemlerin kavramsal analizi [Conceptual analysis of multiplication and division problems in fractions posed by preservice elementary mathematics teacher]. Hacettepe Üniversitesi Ë̆itim Fakültesi Dergisi [Hacettepe University Journal of Education], 41, 231-243. https://doi.org/10.17556/erziefd.440207

Işık, C., \& Kar, T. (2012). İlköğretim matematik öğretmeni adaylarının kesirlerde bölmeye yönelik kurdukları problemlerde hata analizi [Error analysis in problems of primary mathematics teacher candidates for the division of fractions]. Educational sciences: Theory \& practice, 12(3), 2289-2309. Retrieved from http://www.acarindex.com/dosyalar/makale/acarindex-1423931608.pdf

Işıksal, M. (2006). A study on pre-service elementary mathematics teachers' subject matter knowledge and pedagogical content knowledge regarding the multiplication and division of fractions (Doctoral Dissertation, Middle East Technical University, Ankara).

Kadhi, T. (2005). Online assessment: A study of the validation and implementation of a formative online diagnostic tool in developmental mathematics for college students (Doctoral Dissertation, Office of Graduate Studies of Texas A\&M University, Texas).

Karaağaç, M. K., \& Köse, L. (2015). Öğretmen ve öğretmen adaylarının öğrencilerin kesirler konusundaki kavram yanılgıları ile ilgili bilgilerinin incelenmesi [Examination of pre-service and in-service teachers' knowledge of students' misconceptions on the topic of fractions]. Sakarya Üniversitesi Eğitim Fakültesi Dergisi [Sakarya University Journal of Education], 30, 72-92. https://doi.org/10.14686/buefad.310566 
Karacaoğlu, Ö. C. (2008). Öğretmenlerin yeterlilik algıları [The perceptıons of teachers' sufficıency], Yüzüncü Yll Üniversitesi Eğitim Fakültesi Dergisi [Yuzuncu Yıl University Journal of Education], 5(1), 70-97. https://doi.org/10.23891/efdyyu.2019.122

Karasar, N. (2012). Bilimsel araştırma yöntemi [Scientific research method]. Ankara: Nobel.

Keijzer, R., \& Terwel, J. (2003). Learning for mathematical insight: A longitudinal comparative study on modelling. Learning and Instruction, 13, 285-304. https://doi.org/10.1016/s0959-4752(02)00003-8

Kieren, T. E. (1993). Rational and fractional numbers: From quotient fields to recursive understanding. In T. P. Carpenter, E. Fennema, \& T. A. Romberg (Eds.), Rational numbers: An integration of research (pp.49-84). Mahwah, New Jersey: Lawrence Erlbaum.

Lamon, S. J. (2007). Rational numbers and proportional reasoning: Toward a theoretical framework for research. In F. K. Lester (Ed.), Second Handbook of research on mathematics and learning (pp. 629-667). National Council of Teachers of Mathematics. Virginia: Restorn.

Lamon, S. J. (2012). Teaching fractions and ratios for understanding: Essential content knowledge and instructional strategies for teachers. New York: Routledge. https://doi.org/10.4324/9780203803165

Lesh, R., Post, T. R., \& Behr, M. (1988). Proportional reasoning. In H. James, \& B. Merlyn (Eds.), Number concepts and operations in the middle grades (pp. 93-119). NCTM, Virginia: Reston.

Lorenzo-Seva, U., \& Ferrando, P. J. (2013). Factor 9.2: A comprehensive program for fitting exploratory and semiconfirmatory factor analysis and IRT models. Applied Psychological Measurement, 37(6), 497-498. https://doi.org/10.1177/0146621613487794

Lorenzo-Seva, U., \& Van Ginkel, J. R. (2016). Multiple imputation of missing values in exploratory factor analysis of multidimensional scales: estimating latent trait scores. Anales de Psicologia/Annals of Psychology, 32(2), 596-608. https://doi.org/10.6018/analesps.32.2.215161

Ma, L. (2010). Knowing and teaching elementary mathematics: Teachers' understanding of fundamental mathematics in China and the United States. Routledge. https://doi.org/10.4324/9780203856345

McDiarmid, G. W., \& Ball, D. L. (1989). The teacher education and learning to teach study: An occasion for developing a conception of teacher knowledge. Technical Series, 1, 1-89. Retrieved from https://files.eric.ed.gov/fulltext/ED341681.pdf

MEB (Ministry of Education). (2005). Illköğretim matematik dersi (1- 5 sinıflar) öğretim programı [Elementary mathematics curriculum (1- 5 classes)]. Ankara: Devlet Kitaplar1 [State Books].

MEB (Ministry of Education). (2013). Ortaokul matematik dersi (5- 8 sinuflar) ögretim programı [Secondary school mathematics curriculum (5- 8 classes)]. Ankara: Devlet Kitapları [State Books].

MEB (Ministry of Education). (2015). İlköğretim matematik dersi (1- 4 sinıflar) öğretim programı [Elementary mathematics curriculum (1- 4 classes)]. Ankara: Devlet Kitapları [State Books].

Mumcu, H. Y. (2017). Pedagojik alan bilgisi bağlamında öğretmen adaylarının kesirlerle ilgili kavram yanılgılarını giderme yeterliklerinin farklı değişkenlere göre incelenmesi [Examination of Pre-Service Teachers' Ability to Eliminate Misconceptions about Fractions in terms of Pedagogical Content Knowledge According to Different Variables]. Bartın Üniversitesi Ĕ̈itim Fakültesi Dergisi [Bartin University Journal of Faculty of Education], 6(3), 1264-1292. https://doi.org/10.14686/buefad.337019

Newton, K. J. (2008). An extensive analysis of preservice elementary teachers' knowledge of fractions. American Educational Research Journal, 45(4), 1080-1110. https://doi.org/10.3102/0002831208320851

Olkun, S., \& Toluk, Z. (2003). Illkogretimde etkinlik temelli matematik öğretimi. Ankara: An1.

Özdamar, K. (2002). Paket programlar ile istatistiksel veri analizi 1 SPSS-Minitab [Statistical data analysis with packet programs 1 SPSS-Minitab]. Eskişehir: Kaan.

Pantziara, M., \& Philippou, G. (2012). Levels of students' "conception" of fractions. Educational Studies in Mathematics, 79, 61-83. https://doi.org/10.1007/s10649-011-9338-x

Post, T., Cramer, K., Harel, G., Kiernen, T., \& Lesh, R. (1998). Research on rational number, ratio and proportionality. Proceedings of the Twentieth Annual Meeting of the North American Chapter of the International Group for the Psychology of Mathematics Education, 20(1), 89-93.

Rule, A. C., \& Hallagan, J. E. (2006). Preservice elementary teachers use drawings and make sets of materials to explain multiplication and division by fractions. Paper Presented at the 2nd Annual Preparing 
Mathematicians to Educate Teachers (PMET) Conference at Oswego, New York. Retrieved from https://scholarworks.uni.edu/oermaterials/307

Saxe, G. B., Taylor, E. V, McIntosh, C. \& Geahart, M. (2005). Representing Fractions with standard notations: A development analysis. Journal for Research in Mathematics Education, 36(2), 137-157. Retrieved from http://www.culturecognition.com/sites/default/files/Saxe,\%20Taylor,\%20Gearhart.pdf

Sharma, S. (1996). Applied multivariate techniques. USA: John Wiley \& Sons.

Shulman, L. S. (1986). Those who understand: Knowledge growth in teaching. Educational Researcher, 15(2), 4-14. https://doi.org/10.3102/0013189x015002004

Siegler, R. S., Thompson, C. A., \& Schneider, M. (2011). An integrated theory of whole number and fractions development. Cognitive Psychology, 62(4), 273-296. https://doi.org/10.1016/j.cogpsych.2011.03.001

Sowder, J. T. (1995). Instruction for rational number sense. In J. T. Sowder, \& B. P. Schappelle (Eds.), Providing a Foundation for Teaching Mathematics in the Middle Grades (pp. 15-30). Albany, NY: State University of New York.

Sowder, J. T., \& Wearne, D. (2006). What do we know about eighth-grade student achievement? Mathematics Teaching in the Middle School, 11(6), 285-293.

Steffe, P. L. (2002). A new hypothesis concerning children's fractional knowledge. Journal of Mathematical Behavior, 20, 267-307. https://doi.org/10.1016/s0732-3123(02)00075-5

Stephan M., \& Clements. D.H. (2003). Linear and area measurement in prekindergarten to grade 2. In D.H. Clements \& G. Bright (Eds.), Learning and teaching measurement 2003 yearbook (pp.3-16). NCTM, Virginia: Reston.

Tabanchnick, B. G., \& Fidell, L. S. (2013). Using multivariate statistics (6th ed.). Boston: Pearson.

Taş, U. E., Arıcı, Ö., Ozarkan, H. B., \& Özgürlük, B. (2016). PISA 2015 ulusal raporu [PISA 2015 national report]. Ankara: MEB.

Tashakkori, A., \& Teddlie, C. (2003). The past and future of mixed methods research. From data triangulation to mixed models designs. A. Tashakkori \& C: Teddlie (Eds.), Handbook of mixed methods in social and behavioral research (pp. 209-240). Thousands Oaks, CA: Sage. https://doi.org/10.4135/9781506335193

Toluk, Z. (2002). İlkokul öğrencilerinin bölme işlemi ve rasyonel sayıları ilişkilendirme süreçleri [Conceptual Schemes Used by Elementary School Students for Relating Division and Rational Numbers]. Boğaziçi Üniversitesi Eğitim Dergisi [Boğaziçi University Journal of Education], 19(2), 81-103. Retrieved from https://www.researchgate.net/profile/Zulbiye_Toluk_Ucar/publication/245655388_Children"s_conceptualiz ations_of_the_quotient_subconstruct_of_rational_numbers/links/571634fb08aef165cc2b4dd2.pdf

Toluk-Uçar, Z. (2011). Öğretmen adaylarının pedagojik içerik bilgisi: öğretimsel açıklamalar [Preservice Teachers' Pedagogical Content Knowledge: Instructional Explanations]. Turkish Journal of Computer and Mathematics Education, 2, 87-102. Retrieved from http://dergipark.gov.tr/turkbilmat/issue/21564/ 231439

Turgut, M. F. (1997). Eğitimde ölcme ve değerlendirme [Measurement and evaluation in education]. Ankara: ÖSYM Eğitim.

Uğurlu, C. T., \& Polat, S. (2011). Sınıf öğretmenliği öğrencilerinin öğretmenlik mesleğine ilişkin tutumları [The attitudes of elementary education students towards teaching profession]. Cumhuriyet Üniversitesi Sosyal Bilimler Dergisi [Cumhuriyet University Journal of Social Sciences], 35(1), 68-74. https://doi.org/10.9775/kausbed.2016.037

Umay, A. (1997). Eğitimde ölçme ve değerlendirme [Measurement and evaluation in education]. İzmir: ÖES.

Ünal, I. (1996). Eğitim ve yetiştirme ekonomisi [Education and training economics]. Ankara: Epar.

Van de Walle, J. A., Karp, K. S., \& Bay-Williams, J. W. (2014). Ilkokul ve ortaokul matematiği: Gelişsimsel yaklaşımla ögretim [Elementary and middle school mathematics: Teaching with developmental approach] (7th ed., Trans. S. Durmuş). Ankara: Nobel.

Van De Walle, J. E. (1989). Elementary school mathematics. New York: Longman.

Van-Steenbrugge, H., Lesage, E., Valcke, M., \& Desoet, A. (2014). Preservice elementary school teachers' knowledge of fractions: A mirror of students' knowledge? Journal of Curriculum Studies, 46(1), 138-161. https://doi.org/10.1080/00220272.2013.839003 
Wearne, D., \& Kouba, V. L., (2000). Rational numbers. In E. A. Silver, \& P. A. Kenny (Eds.), Results from the seventh mathematics assessment of the national assessment of educational progress (pp. 163-191). NCTM, Virginia: Reston.

Yanik, H. B. (2015). Rasyonel sayılar [Rational numbers]. In İ. Ö. Zembat, M. F. Özmantar, E. Bingölbali, H. Şandır, \& A. Delice (Eds.), Tanımları ve tarihsel gelişimleriyle matematiksel kavramlar [Definitions and historical development of mathematical concepts] (pp. 95-110). Ankara: Pegem Akademi.

Yanik, H. B., Helding, B., \& Flores, A. (2008). Teaching the concept of unit in measurement interpretation of rational numbers. Elementary Education Online, 7(3), 693-705. Retrieved from http://dergipark.gov.tr/ilkonline/issue/8600/107089

Yenilmez, K., \& Ata, A. (2013). Matematik okuryazarlığı dersinin öğretmen adaylarının matematik okuryazarlığ1 özyeterliğine etkisi [The effect of mathematics literacy lesson on mathematics literacy self efficacy for pre-service teachers]. The Journal of Academic Social Science Studies, 6(2), 1803-1816. https://doi.org/10.17051/ilkonline.2018.418887

Yıldıran, G. (1982). Öğrenme düzeyi ve ürünleri [Learning level and products]. İstanbul: Boğaziçi Üniversitesi.

Yıldırım, A., \& Şimşek, H. (2013). Sosyal bilimlerde nitel araştırma yöntemleri [Qualitative research methods in the social sciences]. Ankara: Seçkin.

Yıldırım, A., Özgürlük, B., Parlak, B., Gönen, E., \& Polat, M. (2016). TIMSS 2015 ulusal matematik ve fen bilimleri ön raporu 4. ve 8. Sinfflar [TIMSS 2015 National Mathematics and Science Pre-report, Grades 4 and 8]. Ankara: MEB.

Zehir, K. (2013). Illköğretim matematik öğretmeni adaylarının kesir işlemlerine yönelik problem kurma becerilerinin incelenmesi [Examination of the problem posing skills elementary mathematics teacher candidates towards fractional operations] (Unpublished doctoral dissertation). Atatürk Üniversitesi Eğitim Bilimleri Enstitüsü, Erzurum. https://doi.org/10.14582/duzgef.496

\section{Note}

Note 1. This study consists of a part of the doctoral dissertation (Primary School Teachers' Knowledge Toward Fractional Meanings and Models Used in Fractions Teaching) which the second author is the consultant of the first author.

\section{Copyrights}

Copyright for this article is retained by the author(s), with first publication rights granted to the journal.

This is an open-access article distributed under the terms and conditions of the Creative Commons Attribution license (http://creativecommons.org/licenses/by/4.0/). 